\title{
Determination of Transition Metals in Cigarette Smoke Condensate by Solvent Extraction and Atomic Absorption Spectroscopy*
}

\author{
by Gerald P. Morie and Peter E. Morrisett \\ Researd Laboratories, Tennessee Eastman Company, Division of Eastman \\ Kodak Company, Kingsport, Tennessee, USA
}

\section{INTRODUCTION}

Certain trace metals which occur in many types of plants occur in tobacco leaves. There is a need to determine if significant amounts of these metals are transferred from the tobacco to cigarette smoke. In addition, certain filter additives composed of transition metal compounds have been used experimentally to reduce the concentration of certain smoke compounds. For example, permanganate salts ( $x$ ) and hopcalite (2) (a $\mathrm{MnO}_{2}$, CuO catalyst) are reported to remove nitrogen oxides from smoke. Thus, there is a need to determine if any of these filter additives are transferred from the filter to the smoke.

The inorganic components of cigarette smoke have been determined by classical colorimetric methods (3). Neutron activation analysis has recently been used by Nakarni et al. (4), Jenkins et al. (5), and Kubota (6) to determine certain inorganic constituents of cigarette smoke. This extremely sensitive technique provides a convenient method for the determination of elements such as sodium, aluminum, potassium, calcium, and copper. However, the usefulness of neutron activation analyses is limited by the availability and cost of the necessary equipment.

Atomic absorption spectroscopy is widely used for the determination of metals. However, the use of it in the determination of metals in cigarette smoke has been limited. One reason for this is the difficulty of converting the sample to a homogeneous solution so that it will pass through the aspirator of the instrument. Secondly, for the determination of the ultratrace quantities of metals in cigarette smoke by atomic absorption, a preconcentration step is often required. Solvent extraction is the method of preconcentration preferred over most other methods. Since atomic absorption spectroscopy provides a high degree of selectivity, the preferred extractants should be applicable over a broad $\mathrm{pH}$ range, and they should react with a large number of metal ions. Ammonium 1-pyrrolidinecarbodithioate is known to form complexes with over 20 metals. These

\footnotetext{
- Presented at the meeting of the CORESTA Smoke Study Group held in Nice, France, September 13-14, 1973.
}

complexes may be extracted from aqueous solutions ( $\mathrm{pH}$ of $x$ to 11 ) into many organic solvents (7). A twofold to threefold increase in the sensitivity of atomic absorption spectroscopy is normally experienced with the proper solvent.

This paper describes a method for the determination of trace transition metals in cigarette smoke by utilizing solvent extraction and subsequent atomic absorption spectroscopy.

\section{EXPERIMENTAL}

\section{Reagents}

Ammonium 1-pyrrolidinecarbodithioate (APCD) was obtained from Eastman Organic Chemicals. Methyl isobuityl ketone (MIBK) was redistilled prior to use.

\section{Apparatus}

Cigarettes were smoked on a 20-port Filtrona Model 200 smoking machine. Except when zinc was to be determined, total particulate matter of the smoke was caught on 70-mm Cambridge filters. For zinc determinations a liquid nitrogen trap (glass) described by Elmenhorst (8) was used to trap the smoke. A specially constructed atomic absorption spectrometer consisting of a Jarral Ash monochrometer and Princeton Applied Research amplifier and preamplifier was used in this work.

\section{Cigarettes and Filters}

Commercial domestic $85-\mathrm{mm}$ cigarettes and reference cigarettes from the University of Kentucky (Kentucky IRx) were used in this work. All cigarettes were conditioned at $60 \% \mathrm{RH}$ and $24^{\circ} \mathrm{C}$ for $4^{8} \mathrm{hr}$. prior to use. Unless otherwise specified, filters were 3.3 den./fil., 42,000 total den. cellulose acetate, and $20 \mathrm{~mm}$ in length.

\section{Analytical Procedure}

Sixty conditioned, $85-\mathrm{mm}$ cigarettes were automatically smoked to 27-mm butt lengths under standard conditions (one $35-\mathrm{ml}, 2-\mathrm{sec}$. puff/min.). The total parti- 
culate matter (TPM) of the smoke was caught on three 70-mm Cambridge filters. These Cambridge filters were placed in a 200-ml, 2-neck round-bottom flask. To the flask $50 \mathrm{ml}$ of concentrated nitric acid was then added. The flask was fitted with a reflux condenser in one neck and a glass stopper in the other neck, and was set in a cylindrical heating mantle. The TPM was digested under reflux conditions for 2 to $3 \mathrm{hr}$.

Because certain metals, such as zinc, are present in Cambridge filter material, an alternate trapping procedure was also used. The smoke from 60 cigarettes was trapped in a liquid nitrogen cold trap. After the cigarettes were smoked, the trap was allowed to warm to approximately $0^{\circ} \mathrm{C}$. Fifty milliliters of concentrated nitric acid were added to the cold trap, the exit was stoppered, and the entrance was fitted with a special reflux condenser. The apparatus was placed in a cylindrical heating mantle, and the mixture was digested under reflux conditions for 2 to $3 \mathrm{hr}$.

After the sample was digested, the heating mantle was replaced with an ice bath which was supported on a magnetic stirrer. The stopper was removed and replaced with a 100-ml dropping funnel containing $50 \mathrm{ml}$ of a $50 \%$ sodium hydroxide aqueous solution. The sodium hydroxide was slowly added to the solution while the solution was stirred. The neutralization reaction was monitored by placing a small drop of solution on $\mathrm{pH}$ paper. When the solution was approximately neutral, $10 \mathrm{ml}$ of a $0.1 \mathrm{M}$ solution of potassium acid phthalate were added to buffer the solution at about $\mathrm{pH}$ 4.0. To remove the glass fibers of the Cambridge filters, the mixture was then filtered through a Buchner funnel containing a polypropylene fabric into a $250-\mathrm{ml}$ separatory funnel. Five milliliters of a $2 \%$ aqueous solution of APCD were then added to the mixture. Twenty milliliters of MIBK were added and the solution was extracted by shaking for $10 \mathrm{~min}$. The organic extract was then analyzed by atomic absorption spectroscopy. When manganese was determined, the MIBK solution was analyzed immediately because the manganese-APDC complex is unstable in this solvent (9).

\section{RESULTS AND DISCUSSION}

The amounts of several metals found in the smoke of the commercial and Kentucky $I R I$ cigarettes are shown in Table 1. The results for manganese, copper, and cobalt agree with those described in previous publications $(4,5)$. The amount of zinc $(0.30 \mu \mathrm{g} / \mathrm{cig}$.) reported by Menden and co-workers (10) was slightly lower than our amount. As indicated in Table 1, the percentage of metals removed by the filters was approximately equal to the percentage of TPM removed $(38 \%)$.

The overall precision of this extraction-atomic absorption method was calculated from a series of eight copper determinations; a standard deviation of $0.02 \mathrm{ppm}$ in solution was obtained. The coefficient of variation of the analysis step of a single extract was approximately $5 \%$ for each metal.
Table 1. Quantities of metals determined in clgarette smoke.

\begin{tabular}{l|c|c|c|c}
\hline \multirow{2}{*}{ Cigarette } & \multicolumn{4}{c}{ Metal, $\mu \mathrm{g} / \mathrm{clg}}$. \\
& $\mathrm{Cu}$ & $\mathrm{Fe}$ & $\mathrm{Mn}$ & $\mathrm{Zn}$ \\
\hline Nonfilter domestic blend & 0.15 & 1.5 & 0.05 & 1.0 \\
$\begin{array}{l}\text { Filter domestic blend* } \\
\text { (same tobacco as nonfilter blend) }\end{array}$ & 0.10 & 0.8 & 0.04 & 0.6 \\
Kentucky 1R1 & 0.18 & 1.7 & 0.05 & 1.2
\end{tabular}

All values represent an average obtained from replicate determinations.

- 20-mm cellulose acetate filter removed $38 \%$ of the TPM from cigarette smoke.

The accuracy of the method was checked by adding a known amount of metal ion to digested smoke samples. The individual metals were determined before and after the addition was made. To a smoke solution containing $0.3 \mu \mathrm{g} / \mathrm{ml}(0.9 \mu \mathrm{g} / \mathrm{cig}$.) of zinc, zinc nitrate was added to give a zinc concentration of $0.6 \mu \mathrm{g} / \mathrm{ml}$ after extraction. The solution was analyzed and $0.55 \mu \mathrm{g} / \mathrm{ml}$ of zinc were found. The extraction-atomic absorption method was three to four times more sensitive than atomic absorption analyses of aqueous solutions. In addition, a 2.5 concentration increase was obtained when the metal ions were extracted into the organic solvent. Thus, the method described in this paper is about six to eight times more sensitive than methods based on atomic absorption of aqueous extracts.

This analytical method is not applicable to all metal ions, but APCD may be used for the quantitative extraction of about 20 to 25 different metal ions. The method showed that cellulose acetate cigarette filters remove about the same percentage of metals and TPM from smoke.

\section{SUMMARY}

A method for the determination of trace transition metals in cigarette smoke is described. The smoke particulate matter is digested in nitric acid, the acid is neutralized, and metal ions are complexed with ammonium 1-pyrrolidinecarbodithioate and extracted with methyl isobutyl ketone. The metals are then determined in the organic solvent by atomic absorption spectroscopy. The sensitivity of the method is enhanced by the use of the methyl isobutyl ketone extraction. The method was evaluated for the determination of manganese, copper, iron, and zinc in the total particulate matter of smoke from University of Kentudky reference cigarettes and from commercial cigarettes. The amounts of these metals found in the smoke of a typical commercial filter cigarette are: $0.04 \mu \mathrm{g} \mathrm{Mn}, 0.10 \mu \mathrm{g} C \mathrm{u}_{\text {, }}$ $0.8 \mu \mathrm{g} \mathrm{Fe}$, and $0.6 \mu \mathrm{g} \mathrm{Zn}$. The method was used to show that cellulose acetate cigarette filters remove about the same percentage of metals as total particulate matter from smoke. 


\section{ZUSAMMENFASSUNG}

Es wird eine Methode für die Bestimmung von Spurenmetallen im Cigarettenrauch beschrieben. Die Partikelphase des Rauches wird in Salpetersäure gelöst, die Säure wird neutralisiert, und die Metallionen werden nach Komplexbildung mit Ammonium-1-pyrrolidin-karbodithioat mit Methylisobutylketon extrahiert. Die $\mathrm{Me}-$ talle werden dann in der organischen Lösung mittels Atomabsorptionsspektroskopie bestimmt. Die Anwendung der Methylisobutylketon-Extraktion erhöht die Empfindlichkeit der Methode. Das Verfahren wurde angewendet für die Bestimmung von Mangan, Kupfer, Eisen und Zink in der Gesamtpartikelphase des Rauches von Versuchscigaretten der Universität Kentudky und von handelsüblichen Cigaretten. In einer typischen Filtercigarette des amerikanischen Marktes fanden sich die genannten Metalle in den folgenden Mengen: $0,04 \mu \mathrm{g} \mathrm{Mn} /$ 0, so $\mu \mathrm{g} \mathrm{Cu} / 0,8 \mu \mathrm{g} \mathrm{Fe} /$ und $0,6 \mu \mathrm{g} \mathrm{Zn}$. Mit Hilfe der Methode konnte gezeigt werden, daß Celluloseacetatfilter aus dem Raudh etwa den gleichen Prozentsatz an Metallen wie an Gesamtpartikelphase entfernen.

\section{RESUME}

On décrit une méthode pour la détermination de traces de métaux en transit dans la fumée de cigarette. La matière particulaire de la fumée est dissoute dans l'acide nitrique, l'acide est neutralisé, les ions métalliques forment un complexe avec l'ammonium x-pyrrolidine-carbodithioate et sont extraits au moyen du méthyle-isobutyle-kétone. On examine ensuite les métaux dans le solvent organique par spectroscopie par absorption atomique. La subtilité de la méthode est assurée par l'extraction au méthyle-isobutyle-kétone. On a fait usage de cette méthode pour la détermination du manganèse, du cuivre, du fer et du zinc dans la matière particulaire totale de la fumée de cigarettes référence de l'université de Kentudky, et de cigarettes commerciales. Dans la fumée d'une cigarette commerciale typique avec filtre on a trouvé les quantités suivantes de ces métaux: $0,04 \mu \mathrm{g}$ Mn, 0,10 $\mu \mathrm{g} \mathrm{Cu}, 0,8 \mu \mathrm{g} \mathrm{Fe}$, et $0,6 \mu \mathrm{g} \mathrm{Zn}$. On a employé cette méthode afin de démontrer que les filtres à acétate de cellulose ôtent de la fumée environ le même pourcentage de métaux que de matière particulaire totale.

\section{REFERENCES}

1. Till, D. E., P. L. Levins, and D. H. Koch: U.S. Patent 3,434,479 (1969).

2. Morie, G. P., and C. H. Sloan: U.S. Defensive Publication, T 901,204.

3. Cogbill, E. C., and M. E. Hobbs: Tob. Sci. I (1957) 68.

4. Nakarni, R. A., and W. D. Ehmann: Radiochem. Radioanal. Lett. 4 (1970) 325.

5. Jenkins, R. W., Jr., R. H. Newman, R. M. Ikeda, and R. D. Carpenter: Anal. Lett. 4 (1971) 451.

6. Kubota, H., M. R. Guerin, and J. A. Carter: CORESTA/Tobacco Chemists' Research Conference held in Williamsburg, Virginia, October 22, 1972.

7. Malissa, H., and E. Scoffman: Microchim. Acta 1955, 187.

8. Elmenhorst, H.: Beitr. Tabakforsch. 3 (1965) 101.

9. Mansell, R. E., and H. N. Emmel: At. Absorption Newsletter 4 (1965) 365.

10. Menden, E. E., V. J. Elia, L. W. Michall, and A. G. Petering: Environ. Sci. Technol. 6 (1972) 830.

The authors' address:

Tennessee Eastman Company, Research Laboratories, Kingsport, Tennessee, 37662, USA. 